要旨 薬物療法, リハビリテーションなど行うも症状改善みられない 症例について1例ではあるが鍼の効果を多角度より計測した。方法は 室温, 湿度とも一定の治療室にて銊治療を行い, 週に 1 度治療前後に おける効果を計測した。結果は接地跡面積や皮膚温など手に関連する 事項には有意差が認められたが，便通など全身症状には明確な改善は みられなかった。前田らと比較した場合，選穴や測定法などに相違が あり，持続時間や作用機序の究明などとともに多くの課題が残された。 臨床的には明確な治療法の確立されていない現在では症状の緩解のみ られる銊治療は試みる価値は充分あると考える。

\section{I はじめに}

進行性全身性硬化症 (Progressive Systemic Sclerosis 以下 PSS 略す)は皮膚をはじめ全身をおか す結合組織疾患の一つで膠原病の中でもとりわけ 難治性疾患とされる。特に四肢末梢部の病変は進 行すると治療困難であり, 明確な方法も確立され ていない”このような末梢部の硬化，レイノー症 状などに対し，銊治療が卓効を呈することがある とされている。そこで今回我々は薬物療法, リ八 ビリテーションなどを行うも症状の改善のみられ ない患者について1例ではあるが鍼の効果を多角 度より計測したので報告する。

\section{II 症例}

症例は昭和55年11月発症の39歳女性。名大内科 にてPSS と診断され, ペニシラミン投与するも全 身重症薬疹おこし, 皮膚科入院となる。薬物療法 としてはユベラ, ウロキナーゼ, ヘパリン投与。

* Toshikazu TAKAGI 点竹鍼炎専門学校

共同研究者：Fujio ITO 犬山中央病院

Key Words : PSS, 接地跡面積, Plantar Analyzer, 少海, 八邪
リハビリテーションとしては水治療法, 他動運動 法, 手指作業療法を行っている。

\section{III 方法}

方法は昭和 57 年 1 月より昭和 58 年 12 月まで週 3 回, 室温 $22^{\circ} \mathrm{C}$, 湿度 $60 \%$ 治療室にて 30 分間の安 静後, 鍼治療を行い, 週に 1 度治療前後における (1)接地跡面積 (2)皮虚温 (3)第 1 ～第 5 指間対立 幅 (4)開口距離 (5)臨床症状, の5 項目について 計測した。銊治療は前田ら ${ }^{2)} の$ 方法に順拠して置 銊を主とし，その内で同側の少海と八邪のうち大 都の 2 点間に $2 \mathrm{~Hz}, 20$ 分間の低周波置針療法を行 った。鍼は少海には寸 3 , No. 5 を八邪には 1 寸, No. 1 を用いた。刺入深度は得気を目標として刺入 し, 患者が疼痛や不快感を覚えない最大の強さと した。

接地跡面積 ${ }^{3)}$ は Plantar Analyzer（浜松ホト二 クス社製 C1827)より得られる手掌面の接地跡投 影像をテレビカメラで描写し, マイクロコンピュ ーターを用いた面積演算器で毎秒60回の計測を行 い,統計処理する装置である(写真 1)。面積変化デ 一夕は集収後，演算処理されてモニタ一上に絶対 值で表示される。表示された接地図形, 統計処理 データはプリンターを介してハードコピーされる。 


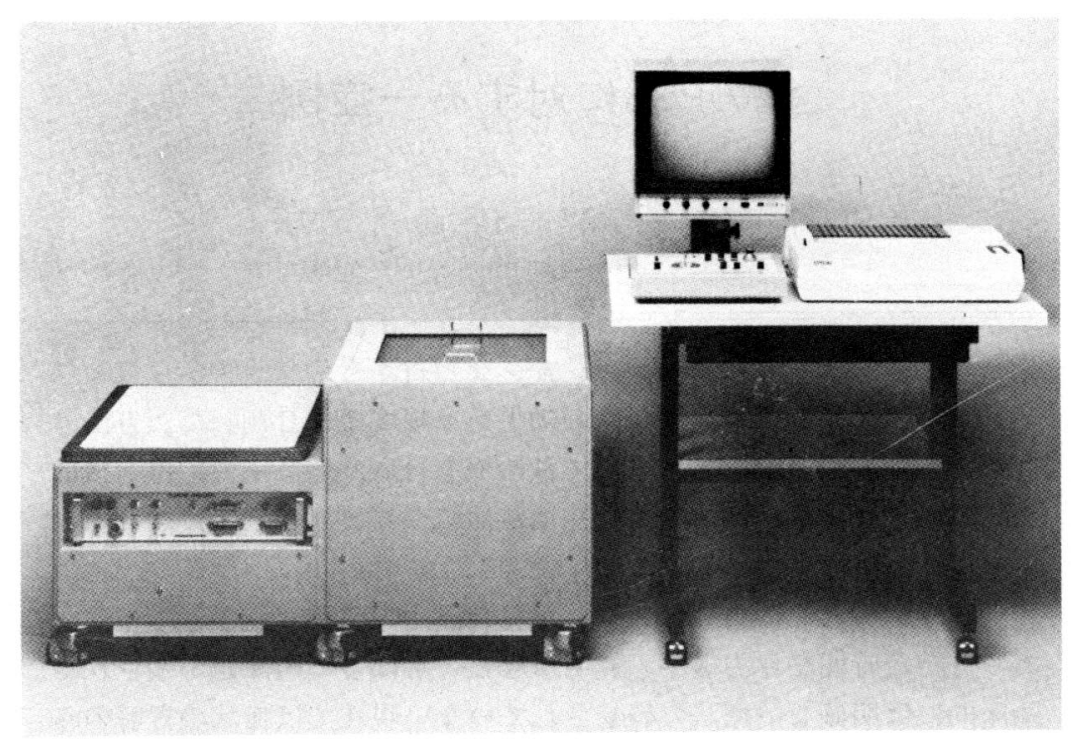

Fhoto 1 Plantar Analyzor

\section{IV 結 果}

1. 接地跡面積: Plantar Analyzer による接地跡 面積は治療前平均面積 $89.84 \pm 24.39 \mathrm{~cm}^{2}$ が治療後は101. $94 \pm 27.95 \mathrm{~cm}^{2}$ と有意に上昇した(図 1 )。特に面積の 増大が手指部に著明であったことは有意義であっ た。

2. 皮䖉温：皮䖉温度計(日本光電製 MGA-III) による第 2 指尖端の皮虚温も治療前平均温度 25 . $42 \pm 1.13^{\circ} \mathrm{C}$ が治療後は $28.71 \pm 1.49^{\circ} \mathrm{C}$ と有意に上 昇した(図 2 )。ただし，一度ではあるが八邪に針 刺入直後，一過性のレイノ一症状をおこしたこと があった。尚，この時は患者が前夜睡眠不足と身 内の不幸などで疲れていたとのことであった。そ れゆえ施術に際しては患者のコンディションの把 握の重要性が再認された。

3 ，第 1 ～第 5 指間対立幅：第 1 ～第 5 指間の対 立幅は治療前平均 $3.24 \pm 0.48 \mathrm{~cm}$ が治療後は $2.98 \pm$ $0.57 \mathrm{~cm}$ とわずかに改善した(図 3 )。

4. 開口距離：治療前後における最大開口距離は 各々 $4.58 \pm 0.28 \mathrm{~cm}, 4.66 \pm 0.19 \mathrm{~cm}$ と有意差は認め られなかった(図 4 )。

5 . 臨床症状：6 項目よりなる臨床症状は手に関 連する項目については改善がみられたが，便通な どには明確な改善はみられなかった(図 5 )。

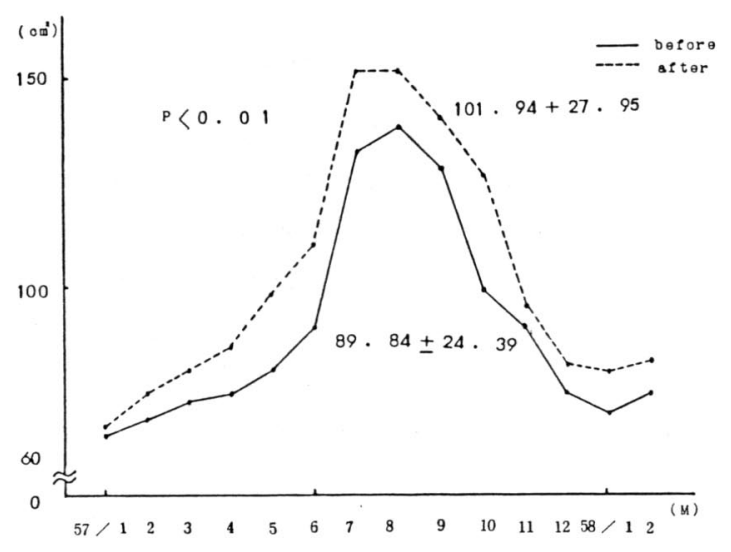

$P \theta$ do $S \operatorname{cop} \theta$

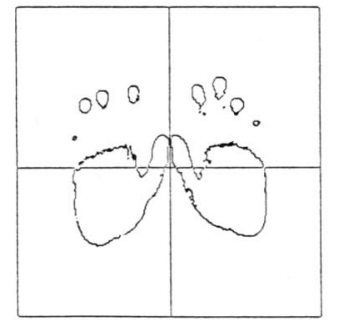

before

FULL AREA

$\begin{array}{lc}\text { MAX } & 139.61 \mathrm{~cm} " \\ \text { MIN } & 13.14 \mathrm{~cm} \\ \text { MEAN } & 13.85 \mathrm{~cm} \\ \text { SD } & 1.92 \mathrm{~cm}^{\circ} \\ \text { SD MM } & 1.43 \% \\ \text { COUNT } & 1200 \%\end{array}$

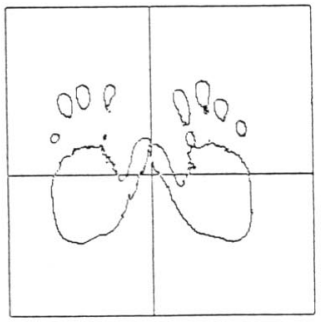

a)เer

FULL AREA
Fig 1 Plantar area 


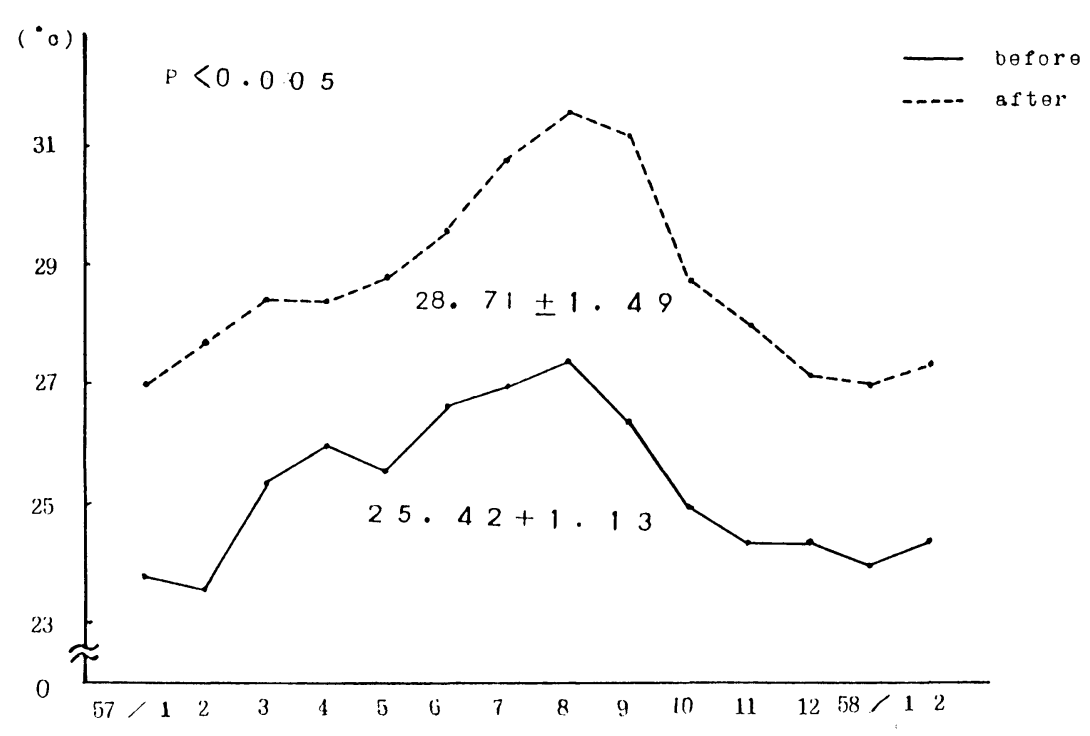

Fig 2 Skin temp

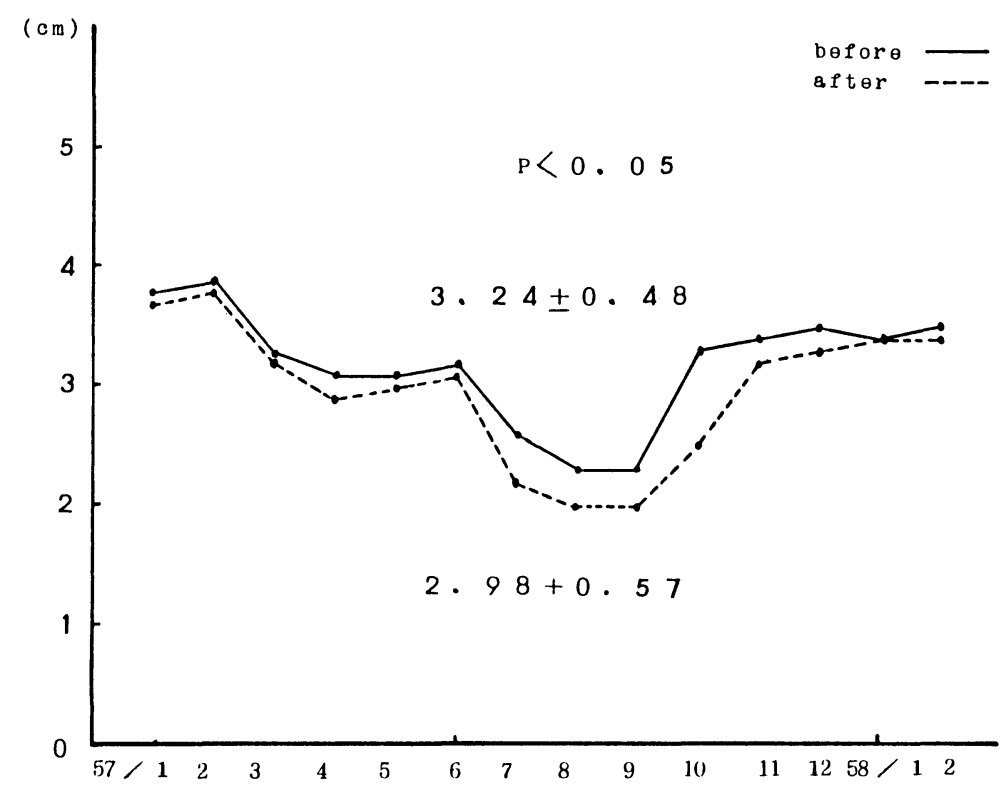

Fig 3 Opposite width

\section{$\mathrm{V}$ 考察}

生体に鍼治療を加之た際には前田らにより指尖 容積脈波の増大など局所の循環動態の変化をはじ め呼吸機能の六進, 一般検査所見などの全身状態 の改善が報告されている。今回我々の行った結果
では局所の緩解はみられたが, 全身状態には期待 した効果はみられなかった。前田らと比較した場 合，選穴や測定方法などに相違があり，持続時間 や作用機序の究明などとともに研究すべき課題が 数多く残された。臨床においては一過性ではあっ たが, 症状の緩解のみられる針治療は明確な治療 


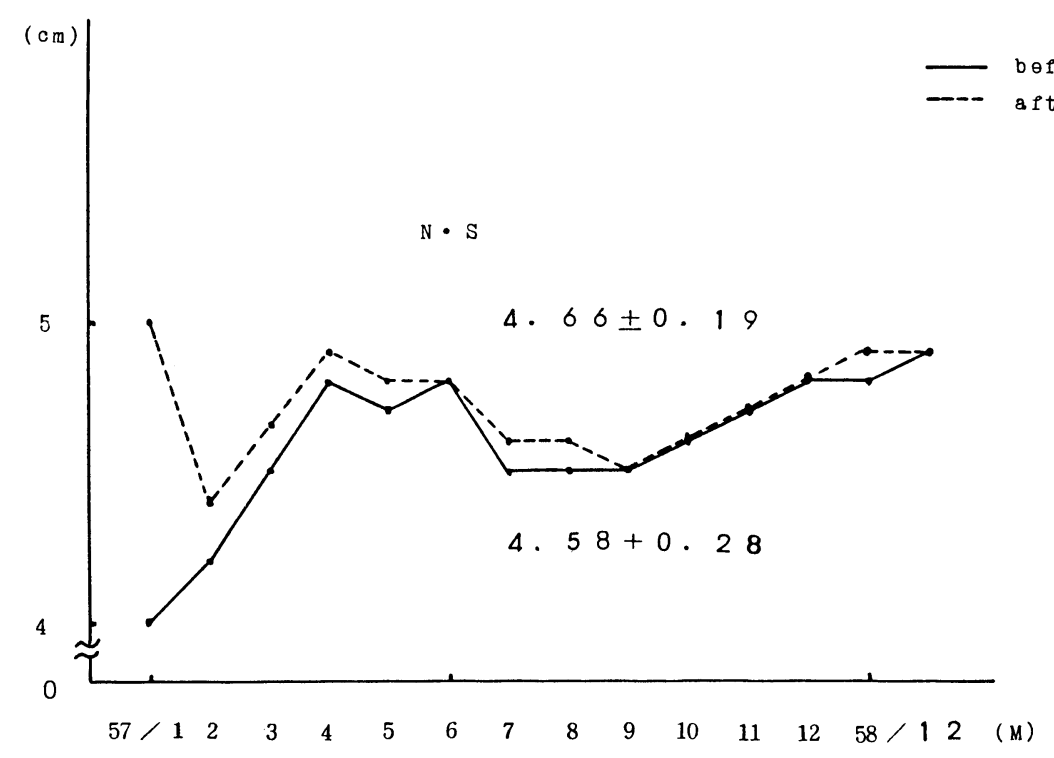

Fig 4 Mouth width

Fig 5 臨 床 症 状

\begin{tabular}{ll|c}
\hline \hline 1. 手をあたたかく感じる。 & H \\
2. 拘縮の改善。 & + \\
3.レイノー症状の改善。 & H \\
4. 手のこわばり。 & + \\
5. 体調の改善。 & - \\
6. 便通など腹部症状。 & - \\
\hline \hline 著 効 + 無効又は不変 & - \\
やや有効 + &
\end{tabular}

\section{参考交献}

1) 石川, 田村: 強皮症, 理学療法と作業療法 Vol. 10. (1976)

2) 前田, 森：PSS の Acropachy の治療一特に低 周波置針療法の効果について一皮膚臨床(1979)

3）高木敏和ほか：片麻軒に対する銊の効果, 一㾏 性について一理療Vol.15 No.3

( T410-21 静岡県田方郡菲山町寺家981-5)

法が確立されていない現在では試みる価值は充分 あると考える。さらに治療に際してはPSSは冬季 に悪化し，夏季に軽快することが知られているの でこれらの点も含めた総合的なアプローチが必要 であると考える。 


\title{
A Case of Progressive Systemic Sclerosis and Acupuncture
}

\author{
Toshikazu Takagi and Fujio Ito
}

Effects of acupuncture were studied using various measurements on a case of PSS (Progressive Systemic Sclerosis) in which symptoms had not been improved by chemo-therapy nor rihabilitation. Acupuncture was undertaken in a therapy room with constant temperature and humidity. The measurements were done before and after the weekly treatment. Although skin temperature and the contact area of the hand showed significant changes, no obvious improvement was seen in systemic symptoms such as bowel movements. Point selection and measurements employed here differ from those of Maeda et al., there remain many questions including duration and mechanism. Since no other methods have been clinically established as effective for treating this disease, acupuncture should be considered. 